\title{
Efektivitas Pemberian Ekstrak Daun Sisik Naga Terhadap Penyembuhan Diare Pada Anak di Desa Penen, Kecamatan Biru-Biru Tahun 2019
}

\author{
Bunga Mari Sembiring ${ }^{(1)}$, Fithri Handayani Lubis ${ }^{(2)}$ \\ Institut Kesehatan Deli Husada Deli Tua \\ Corresponding author : bungamerisembiring@gmail.com
}

bungamerisembiring@gmail.com (1), fithri.handa@gmail.com (2)

\begin{abstract}
ABSTRAK
Latar Belakang: Walaupun persentase diare sebagai penyebab kematian pada anak di Indonesia cenderung menurun, namun angka kesakitan dan kematiannya masih tinggi. Badan Kesehatan Dunia (WHO) memprediksikan pada tahun 2025 masih terdapat lima juta kematian pada anak usia kurang dari 5 tahun, dimana $97 \%$ diantaranya terjadi di negara berkembang dengan penyakit infeksi sebagai penyebab utamanya, salah satunya diare. Pemanfaatan jamu berbasis kearifan lokal merupakan salah satu alternatif pengobatan diare yang diharapkan dapat menjadi terapi rasional yang dapat diterapkan oleh setiap keluarga. Sisik naga atau yang sering disebut ribuan di wilayah sumatera bisa dijadikan alternatif pengobatan herbal diare. Tujuan: Menganalisis pengaruh pemberian ekstrak daun sisik naga terhadap penyembuhan diare pada anak di Desa Penen Kecamatan Biru-Biru. Metode: Eksperimen semu dengan pendekatan sampel satu kelompok pada 95 anak usia 12 sampai 24 bulan. Hasil: Berdasarkan hasil penelitian diketahui bahwa dari 95 anak yang mengalami diare, 41 anak masih mengalami diare setelah diberikan ekstrak daun sisik naga dan sisanya 54 orang tidak lagi mengalami diare setelah diberikan ekstrak daun sisik naga. . Berdasarkan hasil analisis statistik dengan menggunakan uji Mc Nemar diketahui nilai sig. 000. Kesimpulan: Ada perbedaan kejadian diare pada anak yang menjadi responden sebelum dan sesudah pemberian ekstrak daun sisik naga.
\end{abstract}

Kata Kunci : Efektivitas, Ekstrak, Daun Sisik Naga, Penyembuhan, Diare

\begin{abstract}
Background: Although the percentage of diarrhea as a cause of death in children in Indonesia tends to decrease, the morbidity and mortality rates are still high. The World Health Organization (WHO) predicts that in 2025 there will still be five million deaths in children aged less than 5 years, of which 97\% occur in developing countries with infectious diseases as the main cause, one of which is diarrhea. The use of herbal medicine based on local wisdom is an alternative treatment for diarrhea which is expected to be a rational therapy that can be applied by every family. Dragon scales or what is often referred to as thousands in the Sumatran region can be used as an alternative herbal treatment for diarrhea. Purpose: To analyze the effect of giving dragon scales leaf extract on the healing of diarrhea in children in Penen Village, Biru-Biru District. Methods: Quasi-experimental with a one group sample approach to 95 children aged 12 to 24 months. Results: Based on the results of the study, it is known that of the 95 children who had diarrhea, 41 children still experienced diarrhea after being given dragon scales dain extract and the remaining 54 people no longer experienced diarrhea after being given dragon scales leaf extract. Based on the results of statistical analysis using the Mc Nemar test, it is known that the sig. 000. Conclusion: There are differences in the incidence of diarrhea in children who became respondents before and after giving dragon scales leaf extract..
\end{abstract}

Keywords : Effectiveness, Extract, Dragon Scales Leaf, Healing, Diarrhea 
Mari Sembiring S, Handayani Lubis F : Efektivitas Pemberian Ekstrak Daun Sisik Naga Terhadap Penyembuhan Diare Pada Anak di Desa Penen, Kecamatan Biru-Biru Tahun 2019

\section{PENDAHULUAN}

\section{Latar Belakang}

Walaupun persentase diare sebagai penyebab kematian pada anak di Indonesia cenderung menurun tetapi angka kesakitan dan kematian masih tetap tinggi (Amin, 2015). Di Indonesia, diare masih merupakan penyebab kematian utama pada bayi dan anak, berdasarkan data Depkes 2010 diketahui bahwa tiap anak mengalami diare sebanyak 411 per 1000 episode per tahun. Berdasarkan Survei Morbiditas diare 2010, prevalensi diare pada anak tertinggi terjadi pada usia $6-11$ bulan $(21,65 \%), 12-17$ bulan $(14,43 \%)$ dan $24-29$ bulan $(12,37 \%)$ (Kemenkes RI, 2011). World Health Organization (WHO) memprediksikan pada tahun 2025 masih akan terjadi lima juta kematian pada anak usia kurang dari 5 tahun, dimana $97 \%$ terjadi di negara sedang berkembang dengan penyakit infeksi sebagai penyebab utama yang salah satunya adalah diare (WHO, 2009). Oleh karena itu, diperlukan penanganan yang komprehensif dan rasional. Terapi yang rasional diharapkan akan memberikan hasil yang maksimal, oleh karena efektif, efisien dan biaya yang terjangkau (Fithria R.F. and Di ${ }^{\text {eefain }}$ A.R., 2015). Indonesia merupakan negara yang mempunyai potensi keanekaragaman hayati yang sangat tinggi dan menempati urutan ketiga terbesar di dunia setelah Brazil dan Zaire. Sebanyak 40.000 spesies tumbuhan di dunia, Indonesia memiliki 30.000 spesies tumbuhan yang tersebar di hutan tropisnya dan diperkirakan sekitar 3.689 spesies diantaranya merupakan tumbuhan obat (Yuana WT, dkk. 2016). Saat ini, tumbuhan obat yang telah digunakan dalam industri obat tradisional hanya 283 spesies tumbuhan. Eksplorasi dan pengembangan budi daya tanaman obat terus dikembangkan, karena diharapkan dapat mengurangi impor bahan baku obat kimia (Khastini, Rida O, 2013). Salah satu tanaman yang berpotensi sebagai tanaman obat yaitu sisik naga (Drymoglossum piloselloides [L.] Presl.) (Khastini, Rida O, 2013). Sisik naga yang merupakan tanaman epifit dan tumbuh liar di batang dan dahan pohon dapat dengan mudah ditemukan di lingkungan sekitar. Tumbuhan sisik naga merupakan tanaman liar dengan akar rimpang yang panjangnya $5-22 \mathrm{~cm}$, berukuran kecil, merayap, dan bersisik. Secara tradisional, masyarakat menggunakan tanaman ini untuk mengobati radang gusi, sariawan, dan pendarahan (Pratiwi, 2015). Berdasarkan hasil penelitian terdahulu diketahui bahwa terdapat kandungan kimia yang terdapat dalam sisik naga yaitu saponin, polifenol, minyak atsiri, triterpen/sterol, fenol, flavonoid, tanin, dan gula. Hasil dari penelitian-penelitian sebelumnya juga menunjukkan bahwa minyak atsiri, triterpen/sterol, fenol, flavonoid, dan tanin merupakan senyawasenyawa bioaktif yang dapat bersifat antibakteri dan anti fungi (Ratna Widyasari, et, al, 2018). Berdasarkan hasil penelitian in vitro laboratorium yang telah dilakukan oleh peneliti dan mahasiswa bimbingan sebelumnya pada bulan Januari tahun 2019, diketahui bahwa kandungan kimia yang dimiliki daun sisik naga berpotensi sebagai tanaman obat yang bersifat antibakteri $E$. coli yang merupakan penyebab utama diare di negara-negara berkembang terutama Indonesia. Penyebaran bakteri tersebut berkaitan dengan konsumsi air minum dan makanan yang telah terkontaminasi. Selain pengujian aktivitas antibakteri, pada penelitian sebelumnya juga telah dibandingkan aktivitas antibakteri antara dua morfologi daun sisik naga yaitu daun fertil dan daun steril (Yunita, Bungamari, 2019). Informasi yang diperoleh dari keseluruhan penelitian ini dapat berkontribusi sebagai pengetahuan dasar yang untuk dikembangkan lebih lanjut dan diaplikasikan oleh masyarakat guna mendukung program kemandirian obat dengan memanfaatkan potensi alam Indonesia

\section{Perumusan Masalah}

Berdasarkan latar belakang diatas, perumusan masalah dalam penelitian ini adalah bagaimana efektivitas pemberian ekstrak daun sisik naga terhadap pengobatan diare pada anak. 
Mari Sembiring S, Handayani Lubis F : Efektivitas Pemberian Ekstrak Daun Sisik Naga Terhadap Penyembuhan Diare Pada Anak di Desa Penen, Kecamatan Biru-Biru Tahun 2019

\section{Tujuan Penelitian}

Penelitian ini bertujuan yaitu untuk menganalisis pengaruh pemberian ekstrak daun sisik naga terhadap pengobatan diare pada anak

\section{Manfaat Penelitian}

Pengembangan pengobatan herbal berbasis tanaman obat dengan kearifan lokal akan mampu meningkatkan ketersediaan obat rasional dengan akses yang terjangkau dan harga yang relatif lebih murah. Penggunaan ekstrak dari tanaman obat ini diharapkan mampu menjadi alternatif dalam peningkatan kesadaran masyarakat untuk hidup sehat sehingga mampu meningkatkan derajat kesehatannya. Skema penelitian ini adalah penelitian dasar dengan rancangan quasi eksperimen yang sejalan dengan roadmap Kesehatan dan Obat.

\section{METODE PENELITIAN Rancangan Penelitian}

Rancangan penelitian yang akan digunakan adalah quasi eksperiment dengan pendekatan one group sample terhadap 95 anak usia 12 sampai 24 bulan yang bertujuan untuk menganalisis pengaruh pemberian ekstrak daun sisik naga terhadap pengobatan diare pada anak.

\section{Lokasi Penelitian}

Penelitian ini dilakukan di Desa Penen, Kecamatan Biru-biru dengan pertimbangan bahwa daerah tersebut merupakan desa dengan kejadian diare pada anak yang cukup tinggi, berdasarkan hasil observasi lapangan diketahui bahwa masih banyak penduduk yang belum memiliki jamban yang dianggap peneliti sebagai faktor pemicu tingginya kejadian diare pada anak di Desa Penen.

\section{Populasi dan Sampel}

Populasi kasus dalam penelitian ini adalah seluruh anak usia 12 sampai dengan 24 bulan yang bertempat tinggal di Desa Penen, Kecamatan biru-biru, Kabupaten Deli Serdang. Pemilihan sampel dalam penelitian ini menggunakan kriteria Inklusi sebagai berikut:

1. Orang tua dari anak yang akan dijadikan responden bersedia anaknya diikutsertakan menjadi responden penelitian

2. Responden (anak usia 12-24 bulan) didiagnosa menderita diare oleh petugas kesehatan pada saat penelitian dilaksanakan

3. Berada dilokasi saat pelaksanaan penelitian.

Besar sampel dalam penelitian ditetapkan berdasarkan rumus crossec tional dengan populasi yang tidak diketahui yang diperoleh dengan rumus (Lameshow). Berdasarkan perhitungan diperoleh sampel minimal sebanyak 95 responden. Metode penarikan sampel yang digunakan adalah consecutive sampling, dimana semua anak yang memenuhi kriteria inklusi dimasukkan dalam penelitian sampai jumlah subjek yang diperlukan dipenuhi.

\section{Metode Pengumpulan Data}

Data primer Data yang di peroleh langsung dari responden melalui pemantauan proses penyembuhan diare pada anak dengan menggunakan instrumen . Data sekunder adalah data yang diperoleh dari Puskesmas Penen mengenai data anak usia 12-24 tahun yang didiagnosa mengalami diare saat melakukan kunjungan ke Puskesmas. Data sekunder juga diperoleh dari Dokter yang akan diperbantukan sebagai Petugas lapangan saat pelaksanaan penelitian untuk membantu mendiagnosa kondisi kesehatan anak yang akan dijadikan sebagai responden. 
Mari Sembiring S, Handayani Lubis F : Efektivitas Pemberian Ekstrak Daun Sisik Naga Terhadap Penyembuhan Diare Pada Anak di Desa Penen, Kecamatan Biru-Biru Tahun 2019

Validitas, Reabilitas, dan Analisa Data

Uji validitas dan reliabilitas kuesioner dilaksanakan di Desa Namorambe, Kecamanatan Namorambe. Analisa data difokuskan pada analisa univariat dan bivariat

\section{HASIL PENELITIAN}

Tabel 1. Distribusi Frekuensi Efektifitas Pemberian Ekstrak Daun Sisik Naga terhadap Penyembuhan Diare pada Anak di Desa Penen, Kecamatan Biru-biru

\begin{tabular}{|l|l|l|l|l|l|l|}
\hline & $\begin{array}{l}\text { Kejadian Diare } \\
\text { Setelah } \\
\text { Pemberian } \\
\text { Ekstrak }\end{array}$ & Persent & $\begin{array}{l}\text { Tidak } \\
\text { Diare }\end{array}$ & $\begin{array}{l}\text { Persenta } \\
\text { se }\end{array}$ & Jumlah & $\begin{array}{l}\text { Persenta } \\
\text { se }\end{array}$ \\
\hline Responden & Diare & & & & \\
\hline $\begin{array}{l}\text { Seluruh } \\
\text { responden } \\
\text { mengalami diare } \\
\text { sebelum } \\
\text { pemberian } \\
\text { ekstrak) }\end{array}$ & 41 & 43,16 & 54 & 56,84 & 95 & 100 \\
\hline
\end{tabular}

Hasil penelitian pada tabel 1 menunjukkan bahwa dari 95 anak yang mengalami diare sebanyak 41 anak yang tetap mengalami diare setelah diberikan ekstrak dain sisik naga dan sisanya yaitu sebanyak 54 orang tidak lagi mengalami diare setelah diberikan ekstrak daun sisik naga.

Tabel 2. Efektifitas Pemberian Ekstrak Daun Sisik Naga terhadap Penyembuhan Diare pada Anak di Desa Penen, Kecamatan Biru-biru

\begin{tabular}{|l|l|l|l|}
\hline \multicolumn{1}{|c|}{ Pemberian Ekstrak } & Mean \pm SD & Min.-Max. & Asymp. Sig. \\
\hline Sebelum & $1,00 \pm 0,000$ & $1-1$ & 0,000 \\
Sesudah & $1,57 \pm 0,498$ & $1-2$ & \\
\hline
\end{tabular}

Hasil penelitian pada tabel 2 menunjukkan hasil analisis statistik dengan menggunakan uji Mc Nemar, berdasarkan hasil tersebut diketahui bahwa nilai sig. 000, yang artinya ada perbedaan kejadian diare pada anak yang menjadi responden sebelum dan sesudah pemberian ekstrak daun sisik naga.

\section{PEMBAHASAN}

Diare didefinisikan sebagai kejadian yang berlangsung kurang dari 14 hari dengan frekuensi $\geq 3 x$ per hari disertai pengeluaran tinja yang lunak atau cair yang sering dan tanpa darah atau lendir dalam tinja. Mungkin disertai muntah dan demam (Amin, 2015). Umumnya diare akut yang terjadi di negara berkembang merupakan diare infeksius yang disebabkan oleh virus, bakteri dan parasit (Amin, 2015). Dari beberapa penelitian di Indonesia tentang penyebab diare akut, rotavirus merupakan penyebab tersering, dengan penyebaran tersering melalui transmisi faecal-oral, dan masa inkubasi 1 sampai 3 hari (Fazlisia, 2014). Pada diare infeksius terjadi pengeluaran toksin yang dapat menimbulkan gangguan sekresi serta reabsorpsi cairan dan elektrolit dengan akibat dehidrasi, gangguan keseimbangan elektrolit dan gangguan keseimbangan asam basa (Amin, 2015). Ada 2 prinsip patomekanisme 
terjadinya diare cair akut, yaitu : (1) diare sekretorik disebabkan sekresi air dan elektrolit ke dalam usus. Hal ini terjadi bila absorbsi natrium oleh villi gagal sedangkan sekresi klorida di sel epitel berlangsung terus menerus atau meningkat (Mashoto, Malebo, Misisiri \& Peter, 2014). Hasil akhir adalah sekresi cairan yang mengakibatkan kehilangan air dan elektrolit dari tubuh sebagai tinja cair. Kripta melakukan sekresi aktif klorida dan menghambat absorbsi natrium, klorida dan HCO3- yang dirangsang oleh siklik AMP, siklik GMP dan $\mathrm{Ca} 2+$. Pada diare karena infeksi perubahan ini terjadi karena adanya rangsangan pada mukosa usus oleh toksin bakteri atau virus , (2) diare osmotik disebabkan meningkatnya osmolaritas intra luminal, misalnya absorbsi larutan dalam lumen kolon yang buruk. Sebagai contoh adalah diare yang yang disebabkan Rotavirus. Infeksi Rotavirus umumnya mengenai jejunum, tetapi dapat difus menyebar mengenai seluruh usus halus sehingga menimbulkan diare yang hebat. Virus ini menimbulkan diare dengan cara menginvasi epitel vili sehingga terjadi kerusakan sel yang matur. Sel matur ini akan diganti dengan sel imatur yang berasal dari proliferasi sel- sel kripta. Sel imatur ini mempunyai kapasitas absorbsi yang kurang dibandingkan dengan sel matur dan aktifitas disakaridase yang terdapat di sel imatur ini masih kurang sehingga terjadi gangguan pencernaan karbohidrat. Kedua hal patomekanisme ini dapat terjadi invasi dan destruksi pada sel epitel, penetrasi ke lamina propria serta kerusakan mikrovili usus yang dapat menimbulkan keadaan maldigesti dan malabsorpsi. Bila tidak mendapatkan penanganan yang adekuat pada akhirnya dapat mengalami invasi sistemik (Sutanto I, et al. (2013). Obat antidiare dan antimuntah tidak dianjurkan karena tidak terbukti bermanfaat dalam pengobatan diare bahkan dapat menyebabkan kelumpuhan usus dan bahkan menimbulkan kematian pada bayi (Kemenkes RI, 2011). Penggunaan obat herbal berbasis kearifan lokal menjadi salah satu alternatif pengobatan diare yang diharapkan dapat menjadi terapi rasional yang dapat diaplikasikan oleh setiap keluarga. Salah satu tanaman yang berpotensi sebagai tanaman obat diare yaitu sisik naga (Drymoglossum piloselloides [L.] Presl.) (Yuana WT, dkk, 2016). Secara tradisional, masyarakat menggunakan tanaman ini untuk mengobati radang gusi, sariawan, dan pendarahan. Kandungan kimia yang terdapat dalam sisik naga yaitu saponin, polifenol, minyak atsiri, triterpen/sterol, fenol, flavonoid, tanin, dan gula. Hasil dari penelitian-penelitian sebelumnya menunjukkan bahwa minyak atsiri, triterpen/sterol, fenol, flavonoid, dan tanin merupakan senyawa-senyawa bioaktif yang dapat bersifat antibakteri dan anti fungi (Hamzah, Azis, 2019). Berdasarkan hasil penelitian in vitro laboratorium yang telah dilakukan oleh peneliti dan mahasiswa bimbingan sebelumnya pada bulan Januari tahun 2019, diketahui bahwa kandungan kimia yang dimiliki daun sisik naga berpotensi sebagai tanaman obat yang bersifat antibakteri E. coli yang merupakan penyebab utama diare di negara-negara berkembang terutama Indonesia.

\section{KESIMPULAN}

Berdasarkan hasil penelitian diketahui bahwa dari 95 anak yang mengalami diare sebanyak 41 anak yang tetap mengalami diare setelah diberikan ekstrak dain sisik naga dan sisanya yaitu sebanyak 54 orang tidak lagi mengalami diare setelah diberikan ekstrak daun sisik naga. Diketahui juga berdasarkan hasil analisis statistik dengan menggunakan uji Mc Nemar diketahui bahwa nilai sig. 000, yang artinya ada perbedaan kejadian diare pada anak yang menjadi responden sebelum dan sesudah pemberian ekstrak daun sisik naga. 
Mari Sembiring S, Handayani Lubis F : Efektivitas Pemberian Ekstrak Daun Sisik Naga Terhadap Penyembuhan Diare Pada Anak di Desa Penen, Kecamatan Biru-Biru Tahun 2019

\section{DAFTAR PUSTAKA}

Amin L.Z., (2015), Tatalaksana Diare Akut, Continuing Medical Education, 42 (7), 504508.

Fazlisia, (2014). Uji daya hambat sabun cair cuci tangan pada restoran waralaba di kota padang terhadap pertumbuhan bakteri Escherechia coli dan Staphylococcus aureus secara In Vitro. Jurnal Kesehatan Andalas, 3, (3).

Fithria R.F. and Diefain A.R., (2015), Rasionalitas Terapi Antibiotik Pada Pasien Diare Akut Anak Usia 1-4 Tahun di Rumah Sakit Banyumanik Semarang Tahun 2013, Pharmacy, 12 (02), 197-209. P-ISSN: 1693-3591. e-ISSN: 2579-910X

Hamzah, Azis, (2019). Analisis In Vitro Aktivitas Antibakteri Daun Sisik Naga (Drymoglossum Pilosellaoides) Terhadap Bakteri Vibrio Harveyi Dan Vibrio Parahaemolyticus. The Journal Of Aquaculture And Fish Health (Jafh0. ISSN (Printed) : 2301-7309 - ISSN (Electronic) : 2528-0864. DOI: Http://Dx.Doi.Org/10.20473/Jafh.v8i2.11984

Kemenkes, RI, (2011). Buku saku petugas kesehatan lima langkah tuntaskan kejadian diare. Jakarta : Kemenkes RI.

Kementerian Kesehatan Republik Indonesia. Situasi diare di Indonesia 2011. Jakarta: Departemen Kesehatan Republik Indonesia; 2011.

Khastini, Rida O, (2013). Uji Aktivitas Ekstrak Air Daun Fertil dan Steril Sisik Naga terhadap Enteropatogenik E. coli. Prosiding Semirata FMIPA Universitas Lampung 2013.

Mashoto, Malebo, Misisiri \& Peter, (2014). Prevalence, one weel incidence and knowledge on causes of diarrhea: household survey of under-fives and adults in Mkuranga district, Tanzania. BioMed Centra, 1 (1).

Notoadmodjo, S, (2010). Metodologi penelitian kesehatan. Jakarta : Rineka Cipta.

Pratiwi (2015)."Aktivitas Antibakteri Fraksi Metanol Herba Sisik Naga (Drymoglossum Piloselloides L) Terhadap Bakteri Escherichia Coli Dan Staphylococcus Epidermidis”. Pontianak:Naskah Publikasi, Fakultas kedokteran, Universitas Tanjungpura.

Ratna Widyasari, Dina Yuspitasari, Fadli Fadli, Athiah Masykuroh, Winda Tahuhiddah, (2018). Uji Aktivitas Antipiretik Ekstrak Daun Sisik Naga(Pyrrosia Piloselloides (L.) M.G. Price) Terhadap Tikus Putih (Rattus Norvegicus) Jantan Galur Wistar Yang Diinduksi Pepton 5\%. Jurnal Ilmu Farmasi Dan Farmasi Klinik (Journal Of Pharmaceutical Science \& Clinical Pharmacy). DOI: Http://Dx.Doi.Org/10.31942/Jiffk.v15i01.2169

Sutanto I, Adjung AS, Ahmad MF, Rasad R, Gandahusada S, Susanto L, et al. (2013). Protozologi. In:Sutanto I, Ismid IS, editor. Buku ajar parasitologi kedokteran. edisi 4. Jakarta: Fakultas Kedokteran Universitas Indonesia; 2013.p.103-82.

WHO, (2009). WHO guidelines on hand hygiene in health care : a summary. WHO

Yuana WT, dkk. (2016). Pemanfaatan tanaman obat tradisional anti diare pada Suku Dayak Dusun Deyah di Kecamatan Muara Uya Kabupaten Tabalong. J.Health.Epidemiol. Commun.Dis. 2016;2(1): 7-13.DOI : 10.22435/jhecds.v2i1.5933.7-13

Yunita, Bungamari, (2019). Uji Efektivitas Antibakteri Ekstrak Daun Sisik Naga (Drymoglossum Piloselloides L) Terhadap Bakteri Escherichia-Coli Tahun 2019. Deli Serdang,: Naskah Publikasi. Institut Kesehatan Deli Husada Delitua.

\begin{tabular}{|l|l|l|l|}
\hline Accepted Date & Revised Date & Decided Date & Accepted to Publish \\
\hline 04 September 2020 & 10 September 2020 & 30 Oktober 2020 & Ya \\
\hline
\end{tabular}

